\title{
'N EVALUERING VAN DIE 6M-SIMULASIE OPLEIDINGSKURSUS VIR ONINGEWYDE SWART WERKERS
}

\section{R. VAN NIEKERK *}

AFDELING OPLEIDINGSTUDIES

NASIONALE INSTITUUT VIR PERSONEEL-NAVORSING

\author{
I. VAN W. RAUBENHEIMER
}

DEPARTEMENT BEDRYFSIELKUNDE RANDSE

AFRIKAANSE UNIVERSITEIT

\section{ABSTRACT}

Evaluation of the 6M Simulation Training Course is discussed with reference to mastery of course content, influence of training on job performance and reaction of course attendants to the course. Results indicate a significant increase in knowledge, irrespective of variables such as age, educational qualifications, years of service, home language, place of origin and job category. A positive change in 34 items related to the job situation and a positive reaction to the course content and training techniques were also found.

Dit is 'n bekende feit dat die Swart werknemer as gevolg van kulturele en sosioekonomiese faktore probleme ervaar met aanpassing by die Westerse nywerheidslewe. SuidAfrika is egter in die posisie dat daar toenemende groter tekorte aan geskoolde werknemers ontstaan. Vanweë die bevolkingsamestelling van die land, word dit aanvaar dat geskoolde werkers grootliks uit Swart geledere gevind sal moet word. Die belangrikheid van doeltreffende opleiding van hierdie bevolkingsgroep het derhalwe in die jongste tyd pertinent onder die aandag van belanghebbendes gekom (Van Niekerk, 1983, p. 15).

So byvoorbeeld is die 6M-Simulasie Opleidingskursus ontwikkel om 'n geïdentifiseerde gebrek aan kennis, met betrekking tot die funksionering van 'n Westerse nywerheidsorganisasie en die rol van die individuele werker in so 'n organisasie die hoof te bied (Oakley, 1980).

Die kursus dek elementêre besigheidsbeginsels en nywerheidskonsepte, gebaseer op die "... six M's of an organisation (men, machines, materials, money, management, market)" (a.w. p.l (1)).

\footnotetext{
* Versoeke vir afdrukke moet aan die skrywer gerig word.
} 
Kursusgangers word ingelig oor die wisselwerking wat daar tussen hierdie faktore bestaan en die invloed wat hulle op die doeltreffendheid van die organisasies kan hê. Die kursusinhoud is organisasie-spesifiek en word deur 'n opgeleide instrukteur deur middel van bepaalde opleidingstegnieke aan groepe van agt tot tien kursusgangers aangebied.

Die doel van hierdie studie was om die effektiwiteit van die 6M-Simulasie Opleidingskursus met betrekking tot vermeerdering van kennis, verandering in werkverrigting en reaksie van kursusgangers te evalueer.

\section{METODE}

Die mate waarin die 6M-Simulasie Opleidingskursus aan die drie genoemde evalueringsmaatstawwe voldoen is elk op 'n besondere wyse nagevors:

\section{Bemeestering van kursusinhoud}

Die mate van bemeestering van kursusinhoud is bepaal deur prestasie op 'n toets wat voor opleiding en weer na opleiding deur 728 kursusgangers voltooi is, te vergelyk. Die toets wat gebruik is, is gebaseer op die meetinstrument wat tydens die ontwikkelingstadium van die kursus herhaaldelik prakties uitgetoets en verfyn is. Die kursusgangers was werknemers van ses organisasies. Die verwantskap tussen prestasie op die toets en bepaalde kategorieveranderlikes, naamlik die invloed van die instrukteur, ouderdom, opleidingskwalifikasies, jare diens by die organisasie, huistaal, plek van herkoms en poskategorie, is ook ondersoek.

\section{Invloed van opleiding op werkverrigting}

'n Vraelys, getiteld "Gedragsevaluering van 6M-Simulasie Opleiding" wat deur die NIPN ontwikkel is, is by twee van die ses organisasies as basis vir onderhoude met verteenwoordigers van lynbestuur gebruik. Die vraelys bestaan uit die volgende 34 werkverwante items wat deur respondente op 'n vyfpuntskaal beoordeel is.

Vermorsing van grondstowwe

Beskadiging van produkte

Korrekte masjienprosedure volg

Aantal uitskot geproduseer

Aanmeld van foutiewe masjinerie

Onderhoud van masjiene 
Optimale voorsiening van grondstowwe aan masjiene

Wegraak van gereedskap

Afwesigheid

Laatkom

Vroeg loop

Ledigheid by die werk

Onveilige optrede

Motivering by die werk

Aanvaarding van opdragte

Uitvoer van opdragte

Diefstal

Hoeveelheid toesig benodig

Houding teenoor produksiedoelwitte

Bereiking van produksiedoelwitte

Houding teenoor oortyd

Houding teenoor bestuur

Houding teenoor toesighouers

Houding teenoor skofwerk

Houding teenoor loonbeleid

Houding teenoor organisasie regulasies

Houding teenoor departementele regulasies

Identifikasie met organisasie

Arbeidsomset

Skakel/Werkskomitee besprekings

Samewerking binne afdelings

Samewerking tussen afdelings

Huishouding

Doeltreffendheid

As gevolg van die invloed wat die toetrede van 'n vakunie by die een organisasie, vermoedelik op die resultate gehad het, is gegewens vir die twee organisasies afsonderlik ontleed.

\section{Reaksie van kursusgangers}


Die genoemde gedragsevalueringslys maak voorsiening vir kommentaar deur respondente by elk van die 34 items. Vir die doe 1 van hierdie studie is aanvaar dat indien waargenome positiewe verandering uitsluitlik aan 6M-Simulasie opleiding toegeskryf word, die opleiding as relevant en toepaslik beskou word (Hamblin, 1974, p.83) en dat dit 'n positiewe reaksie teenoor die opleiding reflekteer.

\section{RESULTATE EN BESPREKING}

\section{Bemeestering van kursusinhoud}

Die gemiddelde aantal foute van die proefgroep op die voortoets 10,14 terwyl dit op die natoets 2,4 was (kyk Figuur 1). Hierdie verskil in kennis was beduidend, $F(3,724)=4,532$ $(\mathrm{p}=, 0000)$.

\section{Invloed van instrukteurs op prestasie}

Instrukteurs het 'n beduidende invloed op die prestasie van hulle kursusgangers uitgeoefen, $F(3,724)=17,754(p=, 0000),(k y k$ Figuur 2$)$.

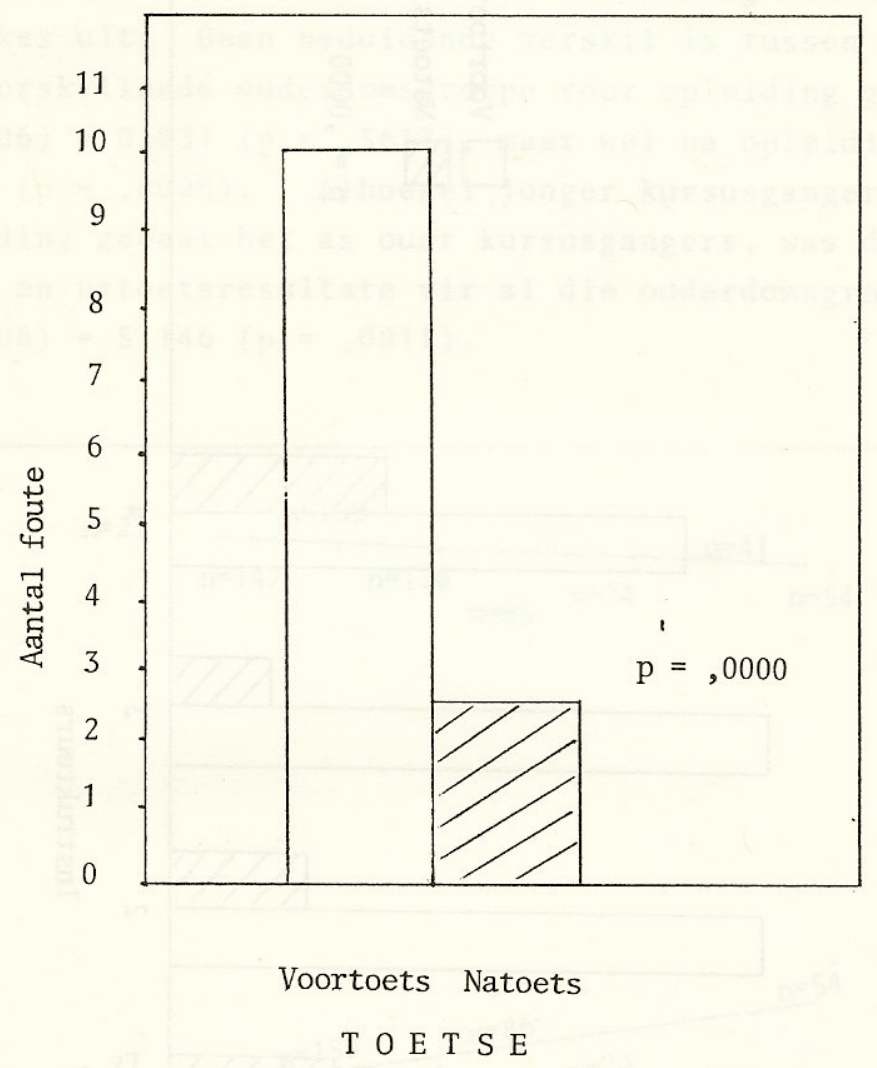

Figuur 1 : Verskil in prestasie tussen voor- en natoetse vir groep as geheel $(n=728)$ 


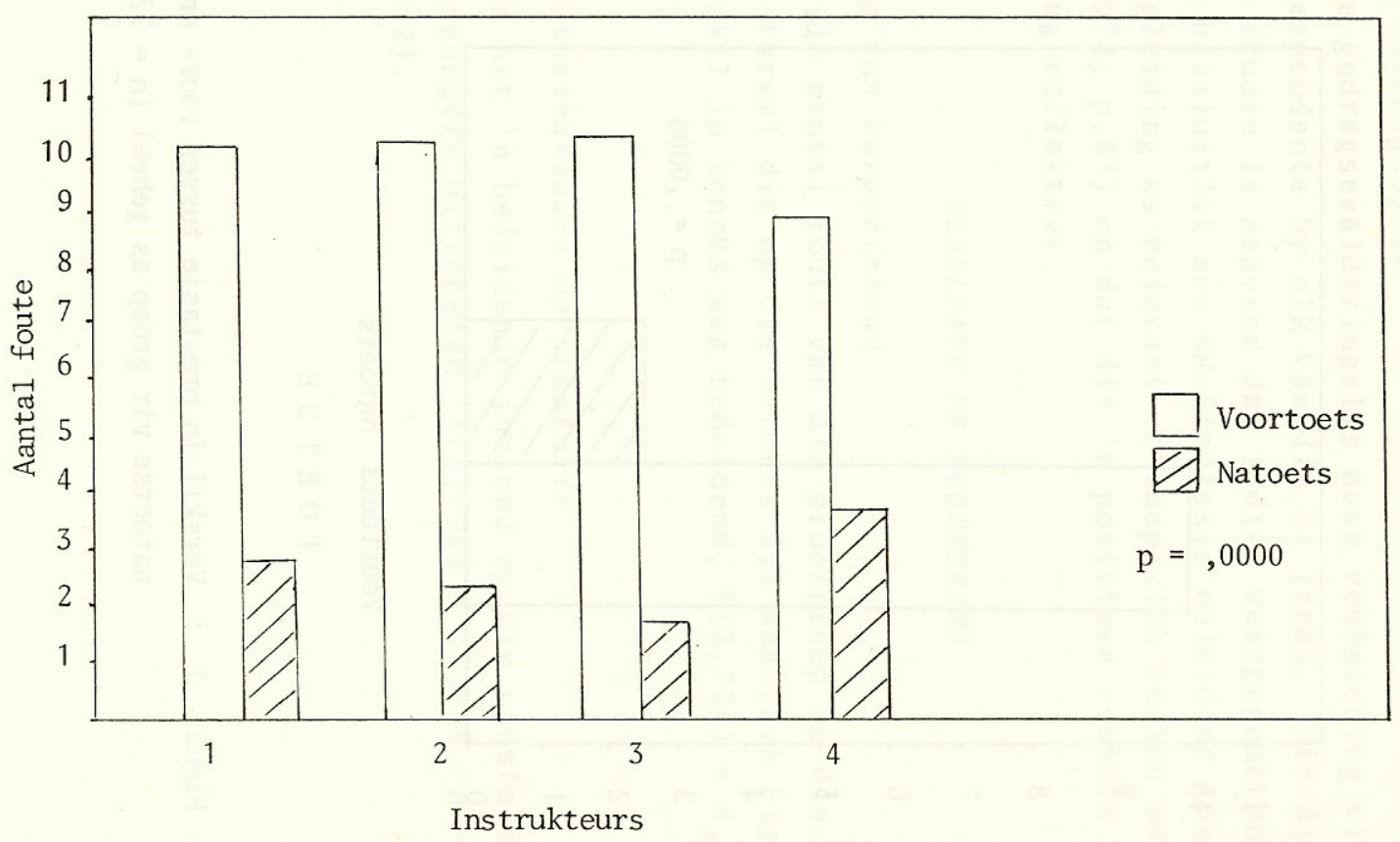

Figuur 2 : Verwantskap tussen prestasie en instrukteur $(n=728)$.

\section{Verwantskap tussen prestasie en ouderdom}

Figuur 3 beeld die resultate met betrekking tot hierdie veranderlikes uit. Geen beduidende verskil is tussen die kennis van die verskillende ouderdomsgroepe voor opleiding gevind nie, $\mathrm{F}(7,706)=0,831(\mathrm{p}=, 5617)$, maar wel na opleiding, $\mathrm{F}(7,706)=7,698$ $(\mathrm{p}=, 0000)$. Alhoewel jonger kursusgangers meer by die opleiding gebaat het as ouer kursusgangers, was die verskil in voor- en natoetsresultate vir al die ouderdomsgroepe beduidend, $\mathrm{F}(7,706)=5,146(\mathrm{p}=, 0011)$.

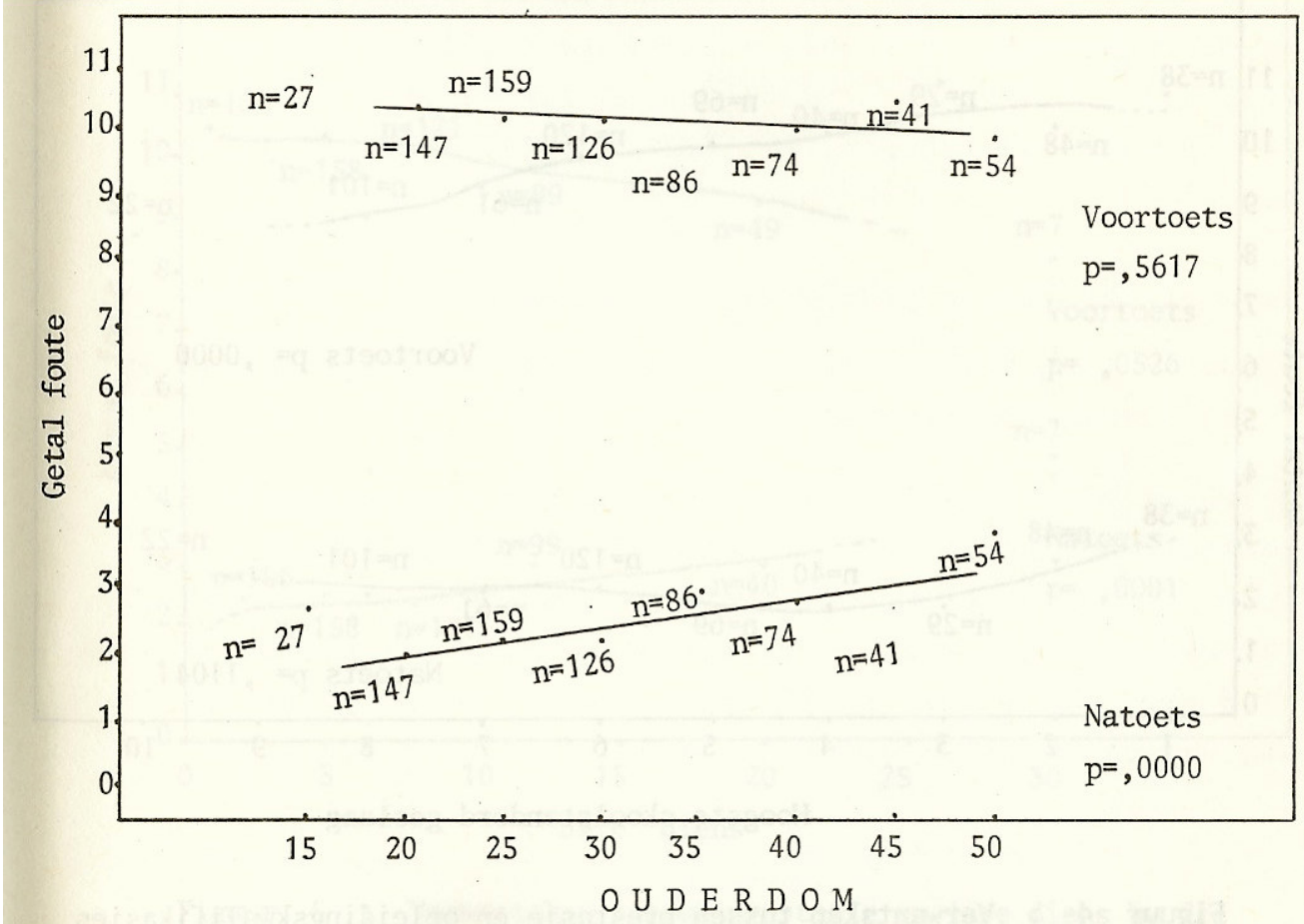

Figuur 3 : Verwantskap tussen prestasie en ouderdom $(n=714)$ 
Verwantskap tussen prestasie en opleidingskwalifikasies

' $n$ Beduidende verwantskap is tussen prestasie op die voortoets en opleidingskwalifikasies gevind, $\mathrm{F}(8,519)=5,469(\mathrm{p}=, 0000)$ maar nie vir natoetsresultate nie, $\mathrm{F}(8,519)=$ $1,641(\mathrm{p}=, 1104)$. Die agterstand wat die laer gekwalifiseerde kursusgangers gehad het is dus deur die opleiding uitgewis (kyk Figuur 4).

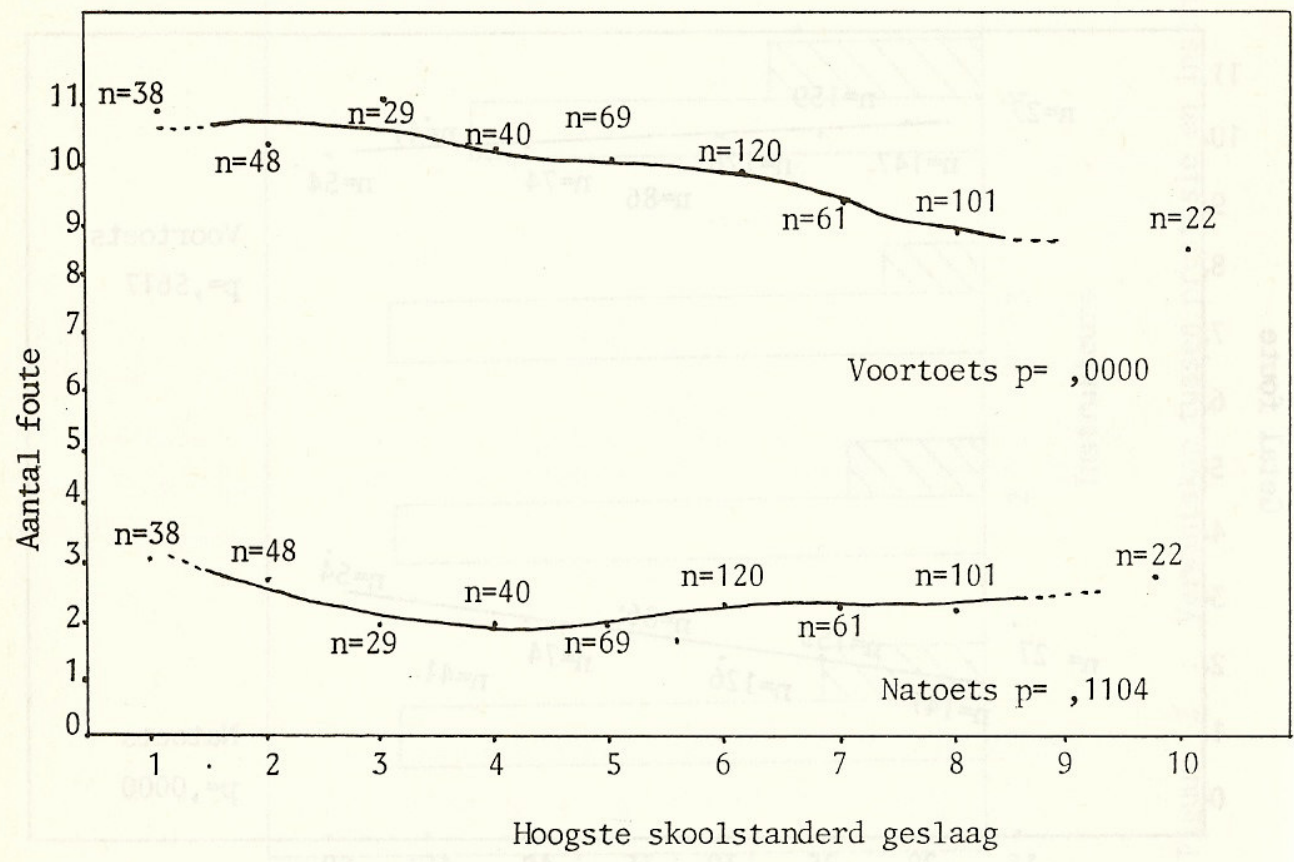

Figur 4 : Verwantskap tussen prestasie en opleidingskwalifikasies $(\mathrm{n}=528)$

Verwantskap tussen prestasie en jare diens

Geen beduidende verskil is in prestasie op die voortoets en jare diens by die organisasie gevind nie, $\mathrm{F}(6,650)=2,089(\mathrm{p}=, 0526)$ maar wel in die geval van die natoets $\mathrm{F}(6,650)=$ $4,866(\mathrm{p}=$,0001) (kyk Figuur 5). Kursusgangers met 'n korter dienstyd het die meeste by opleiding gebaat. 


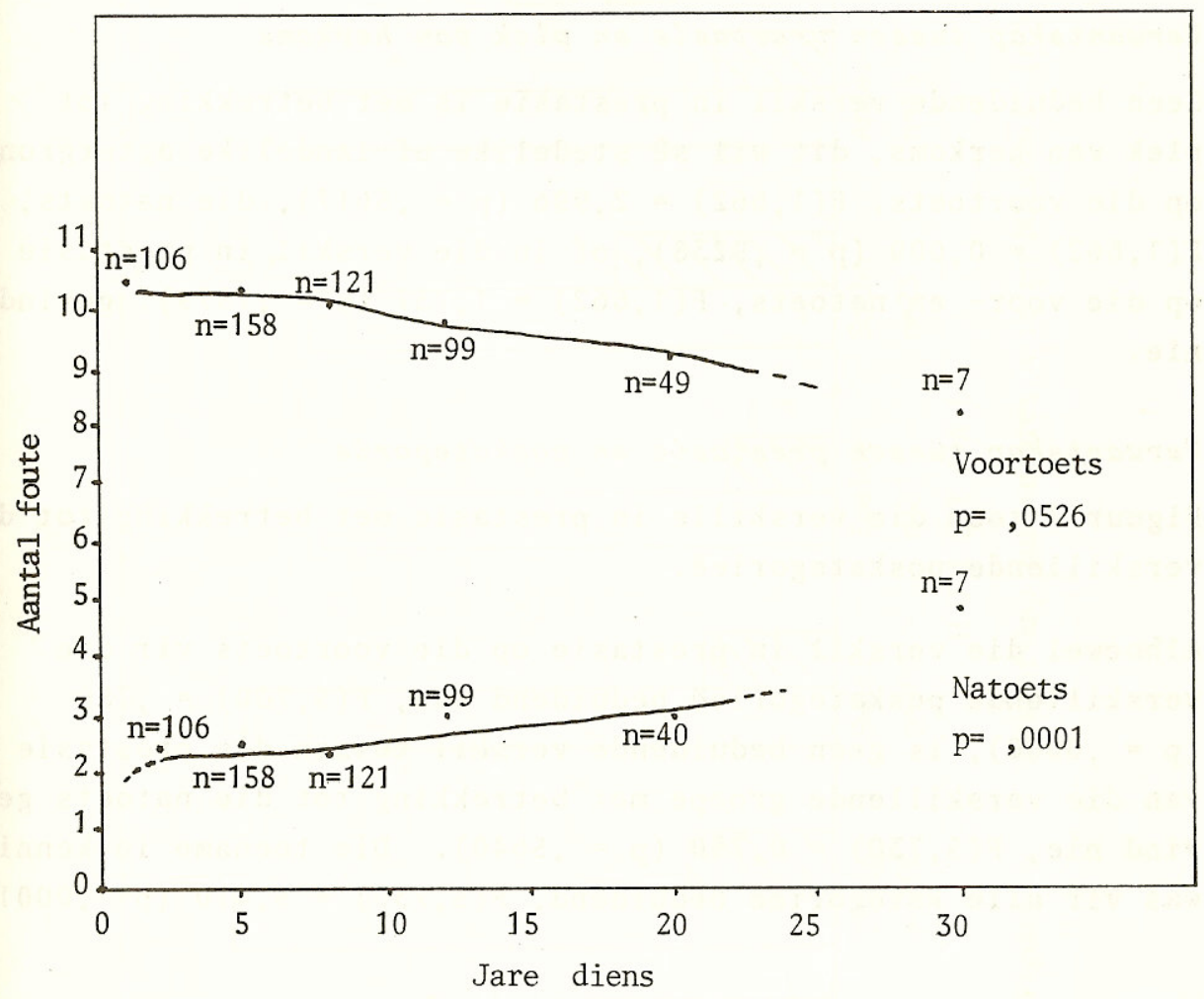

Figur 5 : Verwantskap tussen prestasie en jare diens by die organisasie $(n=657)$

\section{Verwantskap tussen prestasie en huistaal}

Statistiese beduidende verskille is tussen die verskillende taalgroepe (kyk Figuur 6) se prestasie op die voortoets, $\mathrm{F}(4,667)=4,052(\mathrm{p}=, 0030)$, natoets, $\mathrm{F}(4,667)=5,135$ $(\mathrm{p}=, 0004)$, en in die verskil in prestasie tussen die voor en die natoets, $\mathrm{F}(4,667)=4,322$ $(\mathrm{p}=, 0019)$, gevind

\section{Verwantskap tussen prestasie en plek van herkoms}

Geen beduidende verskil in prestasie is met betrekking tot plek van herkoms, dit wil sê stedelike of landelike agtergrond, op die voortoets, $\mathrm{F}(1,662)=2,996(\mathrm{p}=, 5617)$, die natoets, $\mathrm{F}(1,662)=0,009(\mathrm{p}=, 9238)$, of in die verskil in prestasie op die voor- en natoets, $\mathrm{F}(1,662)=$ $1,737(\mathrm{p}=, 1879)$, gevind nie.

\section{Verwantskap tussen prestasie en poskategorie}

Figuur 7 toon die verskille inprestasie met betrekking tot die verskillende poskategorieë.

Alhoewel die verskil in prestasie op die voortoets vir die verskillende poskategorieë beduidend was, $\mathrm{F}(5,730)=, 780(\mathrm{p}=, 0000)$, is geen beduidende verskil tussen die prestasie van die verskillende groepe met betrekking tot die natoets gevind nie, $F(5,730)=0,780$ 
$(\mathrm{p}=, 5640)$. Die toename in kennis was vir alle kategorieë beduidend, $\mathrm{F}(5,730)=5,470$ $(\mathrm{p}=, 0001)$.

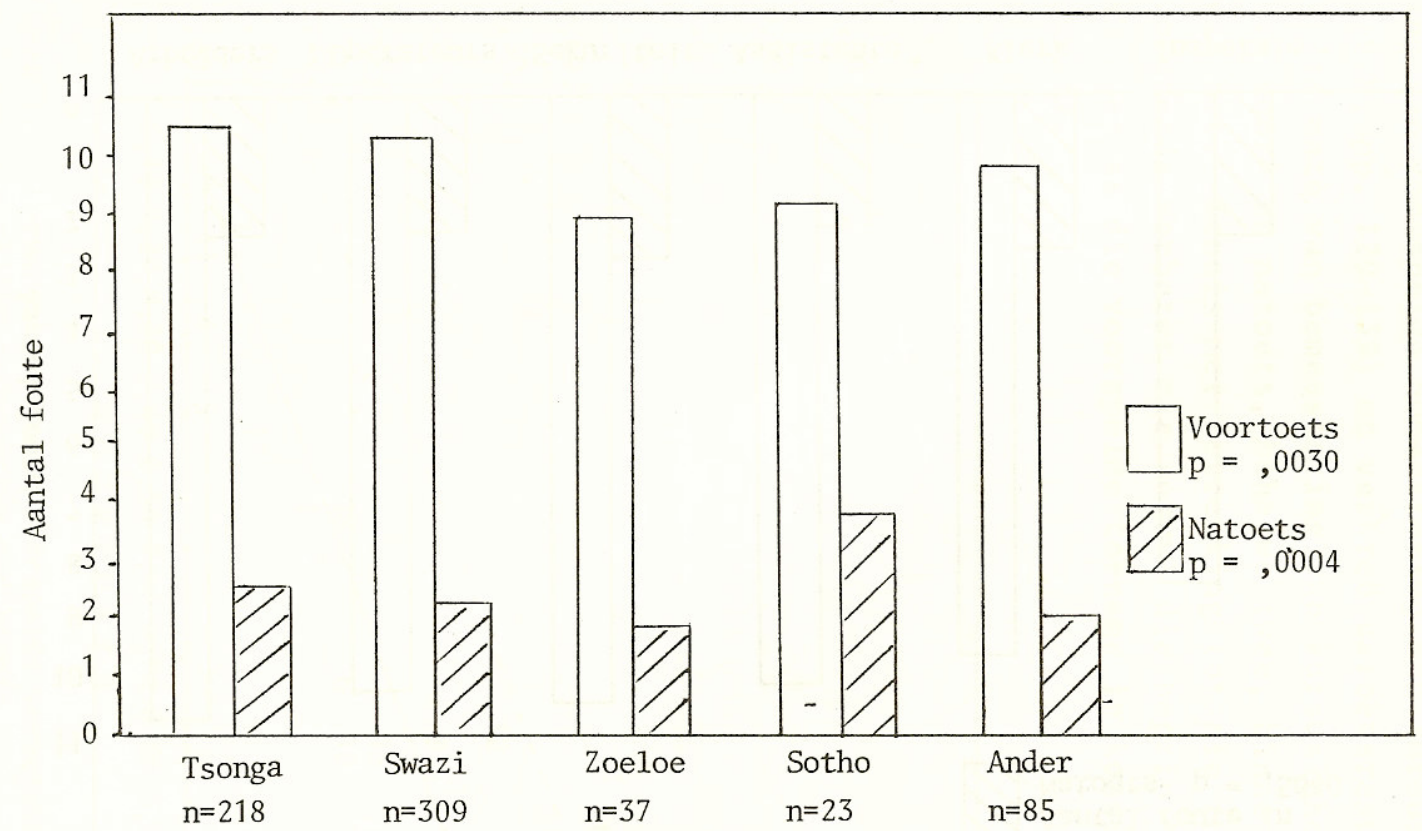

H U I S T A A L

Figuur 6 : Verwantskap tussen prestasie en huistaal $(n=672)$

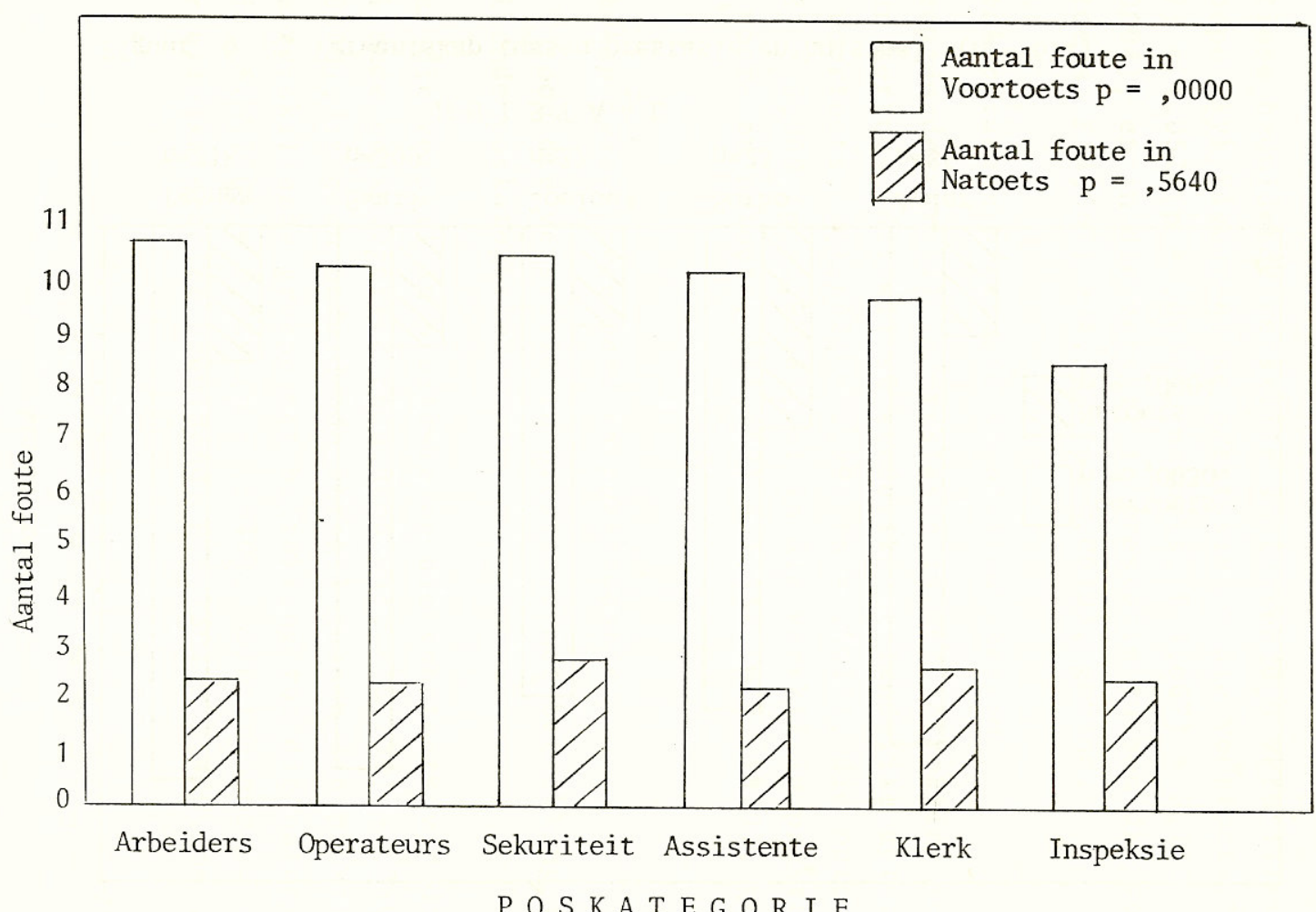

Figuur 7 : Verwantskap tussen prestasie en poskategorie $(n=728)$ 
Verwantskap tussen voorspelde verbetering en natoetsresultate

Vergelyking van voorspelde bemeestering van kursusinhoud (Downie \& Health, 1970, pp. 129-139) en verkreë natoetsresultate het aangedui dat die mate van bemeestering van kursusinhoud vir al die vrae in die voor- en natoets, behalwe twee, binne die verwagte perke geval het. Kennis met betrekking tot die rol van bestuur het nie voldoende verbeter nie terwyl die begrip "kompetisie in besigheid" meer as die voorspelde toename in kennis getoon het (kyk Figuur 8).

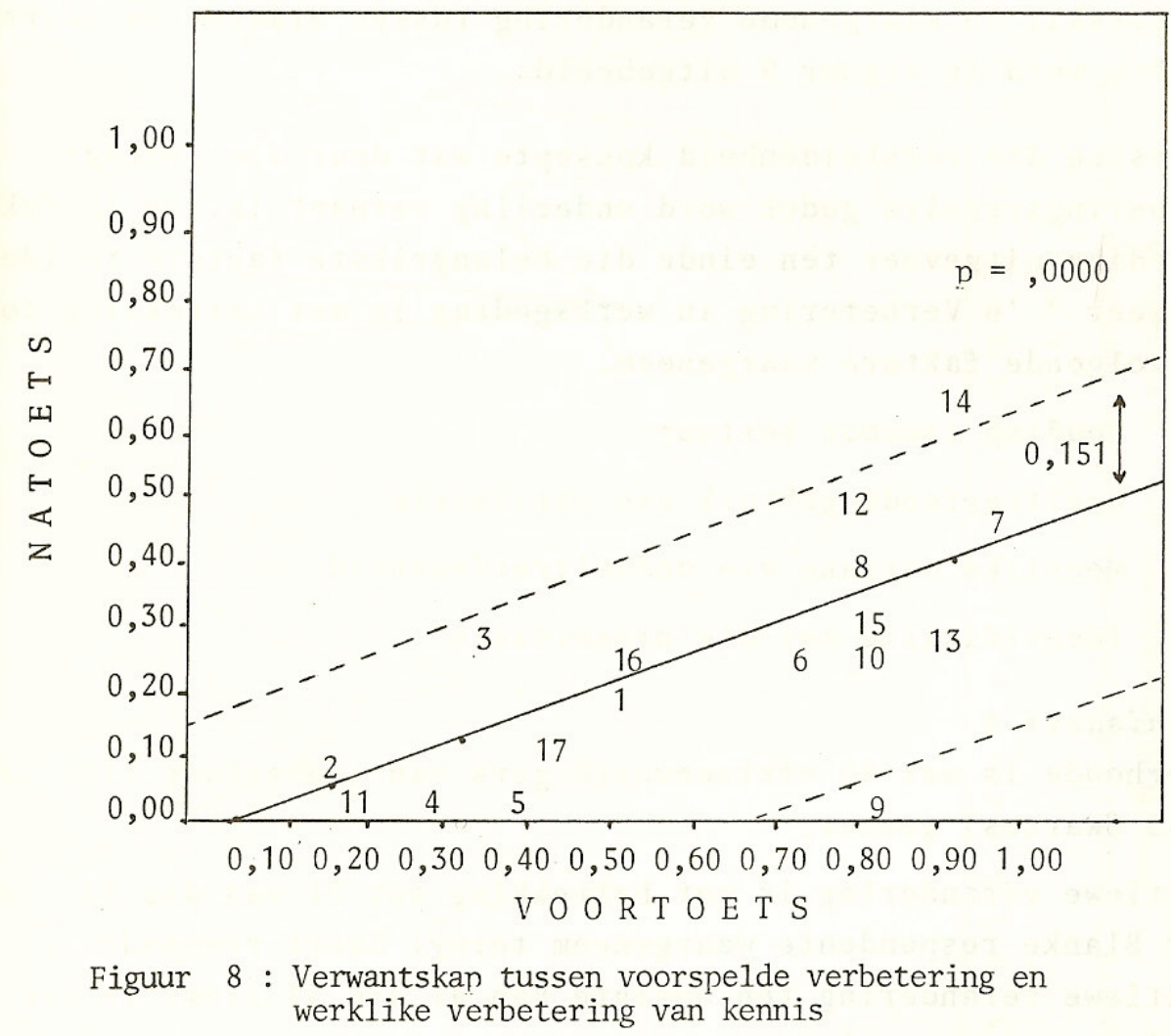

\section{Invloed van opleiding op werkverrigting}

\section{Organisasie A}

Onderhoude met 68 verteenwoordigers van lynbestuur (nege Blankes en 59

Swartes/Indiërs) het aangedui dat alle respondente positiewe verandering in al 34 items in die vraelys ("Gedragsevaluering van 6M-Simulasie Opleiding") by werkers na 6M-Simulasie Opleiding waargeneem het.

Albei groepe het positiewe verbetering in al die items in die vraelys waargeneem.

Die verskil in waargenome verandering tussen Blankes en Swartes/Indiërs word in Figuur 9 uitgebeeld. 
Aangesien die verskeidenheid konsepte wat deur die gedragsevalueringsvraelys gedek word onderling verwant is, is 'n faktorontleding uitgevoer ten einde die belangrikste faktore te identifiseer. 'n Verbetering in werksgedrag is met betrekking tot die volgende faktore waargeneem.

$1:$ Houding teenoor bestuur

2 : Doeltreffende gebruik van masjinerie

3 : Menslike oorsake van ondoeltreffendheid

4 : Identifikasie met die organisasie

\section{Organisasie B}

Onderhoude is met 60 verteenwoordigers van lynbestuur (17 Blankes en 43 Swartes) gevoer.

Positiewe verandering is met betrekking tot 31 van die 34 items deur Blanke respondente waargeneem terwyl Swart respondente positiewe verandering ten opsigte van al die 34 items in die vraelys waargeneem het.

Die verskil in waargenome verandering tussen Blankes en Swartes na 6M-Simulasie opleiding word in Figuur 10 weergegee.

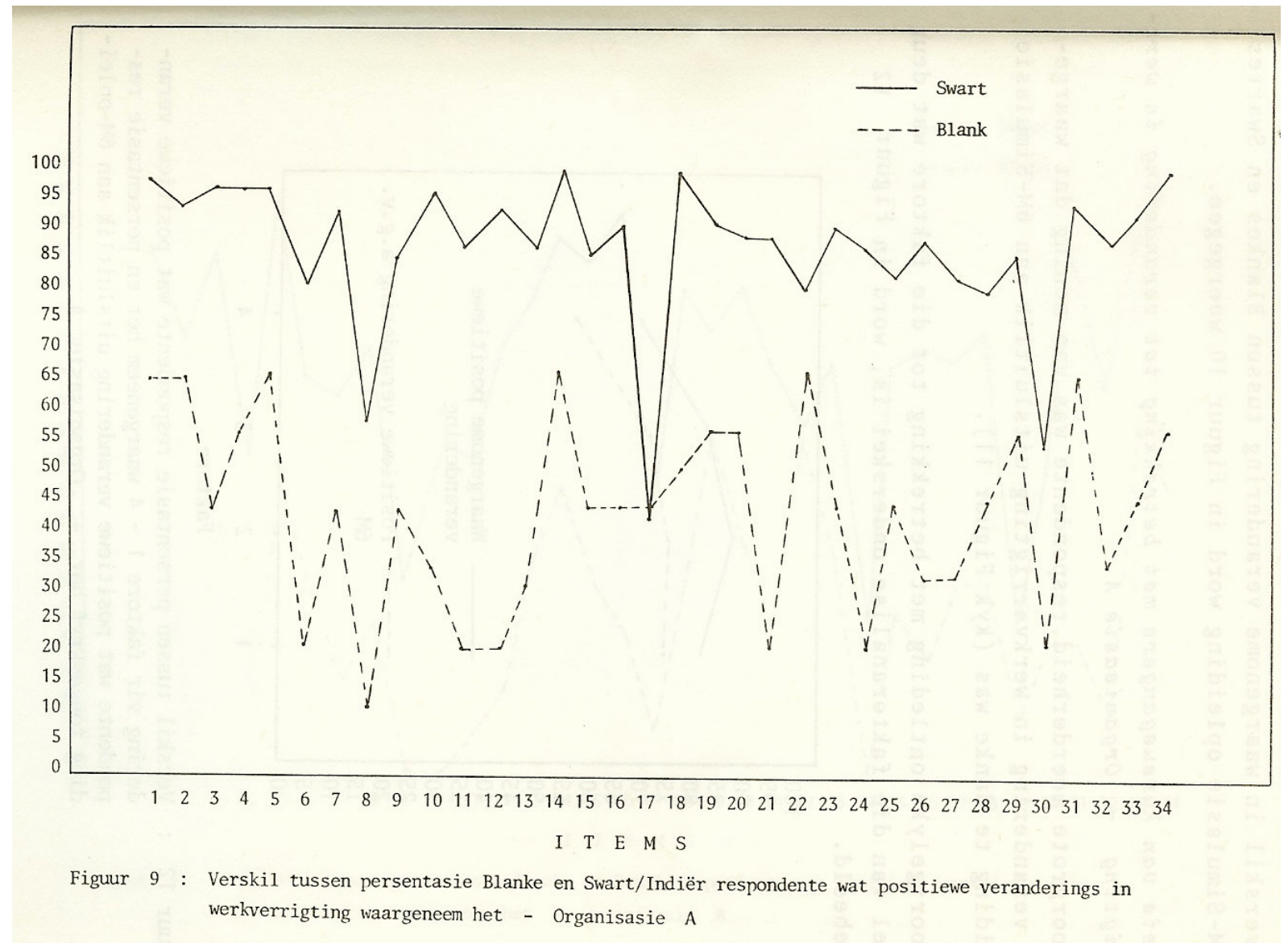




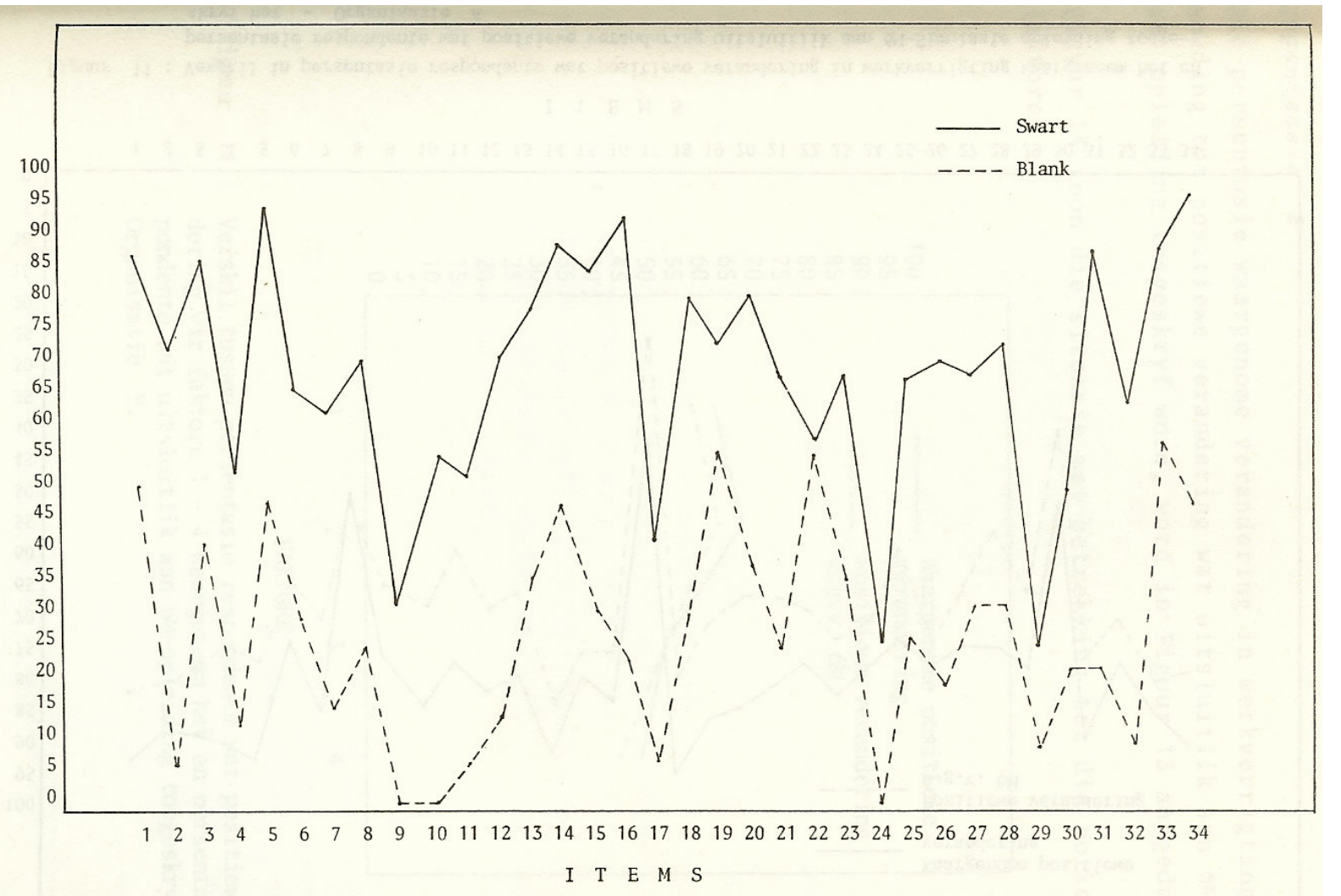

Figuur 10 : Verskil tussen persentasie Blanke en Swart respondente wat positiewe veranderings in werkverrigting waargeneem het - Organisasie B

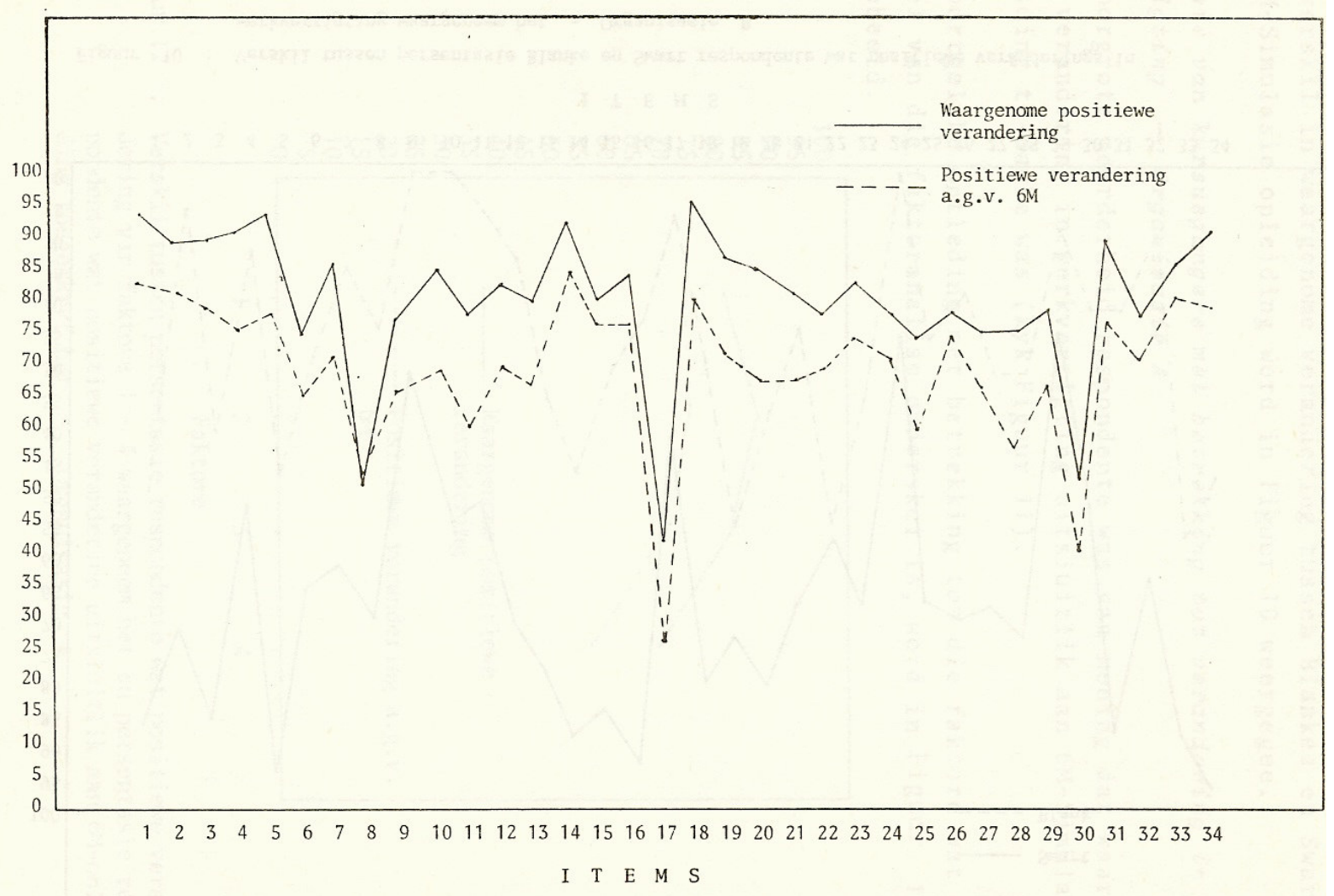

Figuur 11 : Verskil in persentasie respondente wat positiewe verandering in werkverrigting waargeneem het en persentasie respondente wat positiewe verandering uitsluitlik aan 6M-Simulasie opleiding toegeskryf het - Organisasie A 
Reaksie van kursusgangers met betrekking tot verandering in werkverrrigting -

\section{Organisasie A}

Die oorgrote meerderheid respondente was van mening dat waargenome verandering in werkverrigting uitsluiting aan 6M-Simulasie opleiding te danke was (kyk Figuur 11).

' $n$ Soortgelyke ontleding met betrekking tot die faktore wat deur middel van die faktoranalise onderskei is, word in Figuur 12 uitgebeeld.

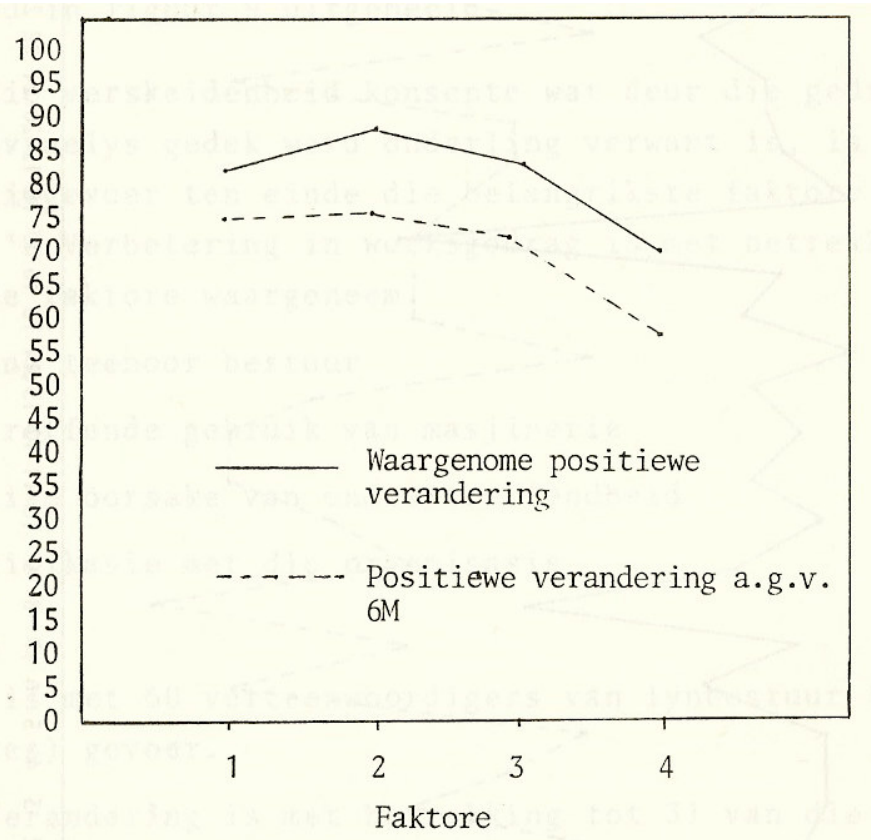

Figuur 12 : Verskil tussen persentasie respondente wat positiewe verandering vir faktore 1 - 4 waargeneem het en persentasie respondente wat positiewe verandering uitsluitlik aan 6M-onleiding toegeskryf het - Organisasie A

\section{Organisasie B}

Die persentasie waargenome verandering in werkverrigting in verhouding tot positiewe verandering wat uitsluitlik aan 6M-Simulasie opleiding toegeskryf word, word in Figuur 13 aangedui.

Figuur 14 toon die situasie met betrekking tot die oorkoepelende faktore. 


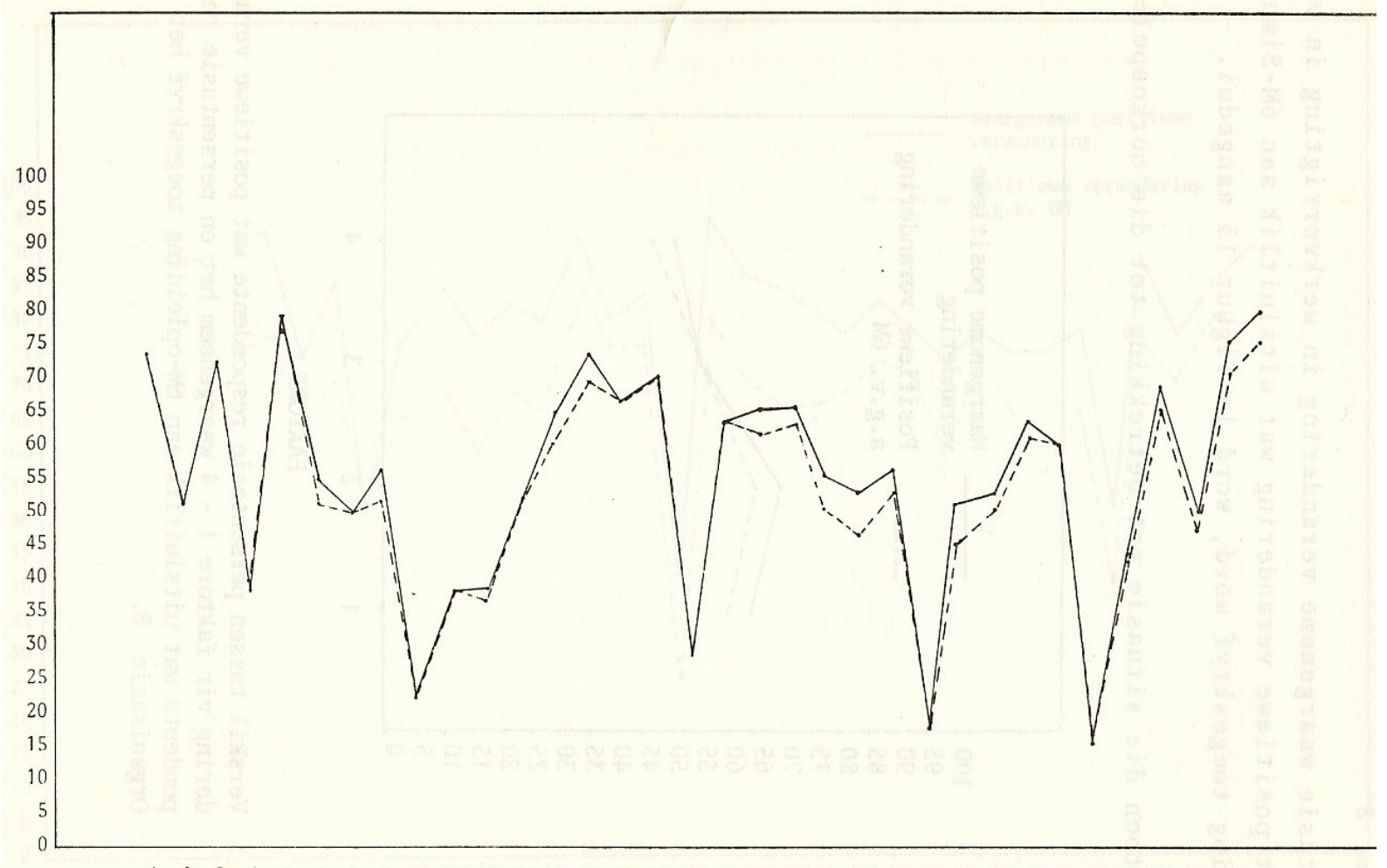

$\begin{array}{llllllllllllllllllllllllllllllllll}1 & 2 & 3 & 4 & 5 & 6 & 7 & 8 & 9 & 10 & 11 & 12 & 13 & 14 & 15 & 16 & 17 & 18 & 19 & 20 & 21 & 22 & 23 & 24 & 25 & 26 & 27 & 28 & 29 & 30 & 31 & 32 & 33 & 34\end{array}$ I $T$ T

Figuur 13 : Verskil in persentasie respondente wat positiewe verandering in werkverrigting waargeneem het en persentasie respondente wat positiewe verandering uitsluitlik aan 6M-Simulasie opleiding toegeskryf het - Organisasie B
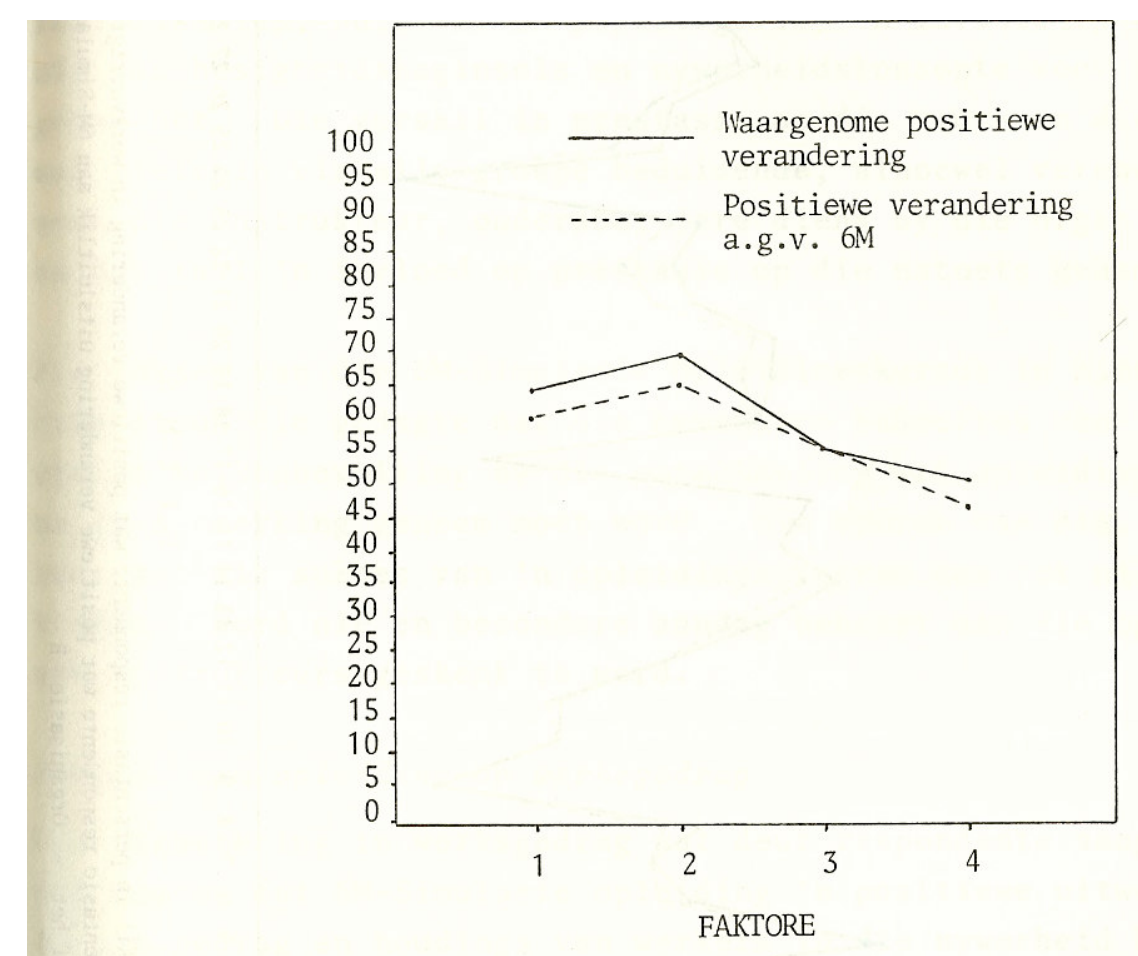

Figuur 14 : Verskil tussen persentasie respondente wat positiewe verandering vir faktore 1 - 4 waargeneem het en persentasie respondente wat uitsluitlik aan 6M-opleiding toegeskryf het Organisasie B. 
Beide figure toon dat respondente positiewe verandering feitlik uitsluitlik aan 6M-Simulasie opleiding toegeskryf het.

\section{GEVOLGTREKKINGS EN AANBEVELINGS}

\section{Bemeestering van kursusinhoud}

Resultate dui aan dat sekere kategorieveranderlikes (opleidingskwalifikasies, huistaal en poskategorie) 'n invloed op die kennis van besigheidsbeginsels en nywerheidskonsepte voor opleiding gehad het. Die verskil in prestasie op die voor- en die natoets was nietemin vir alle groepe beduidende, alhoewel veranderlikes soos die instrukteur, ouderdom, jare diens by die organisasie en huistaal 'n invloed op prestasie op die natoets gehad het.

Die suskes van die 6M-Simulasie Opleidingskursus in hierdie verband steun die gedagte dat die besondere behoeftes van 'n beaalde teikenbevolking by die ontwikkeling van opleidingsprograme in aanmerking geneem moet word. Die bydrae van die instrukteur tot die sukses van 'n opleidingsprogram kan ook nie oorbeklemtoon word nie en besondere aandag behoort aan die opleiding van instrukteurs geskenk te word.

\section{Invloed van opleiding op werksgedrag}

Die verbetering in werksgedrag wat deur respondente aangedui is, dui daarop dat 6MSimulasie opleiding ' $n$ positiewe uitwerking op die gedrag en houdings van werkers in die nywerheid het.

Die besonder positiewe beoordelings van die Swart en Indiër respondente kan moontlik daaraan toegeskryf word dat hierdie groep

- 6M-Simulasie opleiding deurloop het

- $\quad$ met die konsepareas bekend is en dus meer ingestel is op moontlike verandering

- nouer kontak met die werkers het

- $\quad$ die taal van die werkers praat en dus beter met hulle kommunikeer.

Kritiek wat teen hierdie besonder positiewe beoordeling ingebring kan word is dat die respondente die onderhoudvoerder moontlik wou "laat goed voel".

Groter waarde sou aan hierdie gevolgtrekkings geheg kon word indien die stand van sake voor sowel as na opleiding evalueer is en indien beoordeling sonder spesifieke verwysing na die 6M-Simulasieopleiding plaasgevind het. 
Reaksie van kursusgangers m.b.t. verandering in werkverrigting

Resultate toon 'n baie positiewe reaksie tot die kursus. Dit beklemtoon dat die belangrikheid van die aanpassing van die kursusinhoud en opleidingstegnieke by die behoeftes van die teikenbevolking nie uit die oog verloor kan word nie.

Die resultate van hierdie studie toon dat opleiding van Swart oningewyde werkers suksesvol kan wees indien hulle behoeftes en agtergrond tydens die ontwikkeling en aanbieding van kursusse in aanmerking geneem word.

\section{OPSOMMING}

'n Evaluering van die 6M-Simulasie Opleidingskursus word bespreek met verwysing na die bemeestering van kursusinhoud, die invloed van opleiding op werkprestasie en reaksie van kursusgangers. Resultate dui op 'n beduidende toename in kennis ongeag tussenkomende veranderlikes soos ouderdom, opvoedkundige kwalifikasies, jare diens, huistaal, geboorteplek en werkkategorie. ' $n$ Positiewe reaksie op 34 vrae wat verband hou met die werksituasie, en op die kursusinhoud en opleidingstegnieke word ook gerapporteer.

\section{VERWYSINGS}

Downie, N.M. \& Heath, R.W. Basic Statistical Methods (3rd Ed.) New York: Harper \& Row, 1970.

Hamblin, A.C. Evaluation and Control of Training. London: McGraw-Hill, 1974.

Oakley, R.S. The 6M Simulation: Basic Business Concepts in Industry. Instructor's Manual. CSIR Guide K7,73 (First Edition) Johannesburg: CSIR, NIPR, 1980.

Van Niekerk, A.M. 'n Evaluering van die 6M-Simulasie Opleidingsprogram vir Oningewyde Swart Werkers. Magister verhandeling. Johannesburg: Randse Afrikaanse Universiteit, November 1983. 